\title{
Pathogenicity of Four Blue-Stain Fungi Associated with Aggressive and Nonaggressive Bark Beetles
}

\author{
Paal Krokene and Halvor Solheim
}

Norwegian Forest Research Institute, Høgskoleveien 12, N-1432 Ås, Norway. Accepted for publication 1 October 1997.

\begin{abstract}
Krokene, P., and Solheim, H. 1998. Pathogenicity of four blue-stain fungi associated with aggressive and nonaggressive bark beetles. Phytopathology 88:39-44.

The pathogenicity of two isolates of each of four bark beetle-associated blue-stain fungi was evaluated after mass inoculation of about 40-yearold Norway spruce trees (Picea abies). Trees were inoculated with a different isolate of each fungus in 1995 and 1996 at a density of 400 inoculations per $\mathrm{m}^{2}$ in a 1.2 -m-wide band on the lower bole (about 270 inoculations per tree). Trees were felled 15 weeks after inoculation. In 1995, Ceratocystis polonica was the only fungus that had stained the sapwood (56.3\% of cross-sectional sapwood area). It induced five times longer phloem necroses, 21 times more dead cambium, and 11 times more dead phloem than any other fungus. In 1996, C. polonica induced less extensive host symptoms and an unidentified Ambrosiella sp. induced comparable

symptoms to $C$. polonica in the phloem and cambium. No trees showed any foliar symptoms 15 weeks after inoculation, but six out of eight trees inoculated with $C$. polonica in 1995 had only 0 to $25 \%$ functional sapwood and probably would have died if felling had been delayed. This study confirms that $C$. polonica, an associate of the aggressive bark beetle Ips typographus, is pathogenic to Norway spruce. The pathogenicity of the Ambrosiella sp., which is associated with a nonaggressive bark beetle, seems moderate and varies between isolates. The two remaining fungi included in this study (Ophiostoma piceae and a dark fungus with sterile mycelium), which are associated with nonaggressive bark beetles, were nonpathogenic in both experiments. These results are consistent with the hypothesis that aggressive bark beetle species vector virulent fungi that may help them kill trees, but the results also show that some nonaggressive bark beetles may vector phytopathogenic fungi.
\end{abstract}

Microbes often play important roles as mediators in plant-insect interactions (1). Bark beetles feeding in the phloem of conifers have a wide variety of microbial associates that are transported in mycangia, on the exoskeleton, or in the gut $(3,33,52)$. Bacteria, yeasts, and other fungi may condition the host substrate for egg laying and feeding (52), serve as an additional food source for the developing brood $(13,15)$, and produce population-aggregating pheromones (4); in the case of aggressive bark beetles that are able to kill healthy trees, phytopathogenic fungi may help the beetles to overwhelm host defenses $(20,49,52)$. Mediation by phytopathogenic fungi has been proposed as one of the main hypotheses to explain how aggressive bark beetles can overwhelm and kill healthy trees $(10,11,37)$.

The fungi suspected to be involved in overwhelming host defenses are blue-stain fungi in the genera Ceratocystis and Ophiostoma and related anamorph genera such as Graphium and Leptographium (17, 18,52). Most blue-stain fungi are associated with bark beetles, and most conifer bark beetles vector some species of these fungi (16, 35). However, the phytopathogenicity of the fungal associates varies considerably, even between the associates of aggressive bark beetles $(17,33)$. Some blue-stain fungi are relatively pathogenic, and inoculation studies have demonstrated that they can kill mature trees in the absence of their bark beetle vectors $(7,8,29,48)$. For most aggressive bark beetles, the symbiosis between the beetle and their pathogenic blue-stain fungi appears to be mutualistic, since each partner can reduce the difficulties encountered by the other in host colonization (39). The beetles may benefit, since the phytopathogenic fungi can increase the aggressiveness of each beetle and, thus, help them exhaust tree defenses. Benefits to the fungi include dispersal and inoculation into suitable host trees (28).

Corresponding author: P. Krokene; E-mail address: paal.krokene@ nisk.no

Publication no. P-1997-1112-02R

(c) 1998 The American Phytopathological Society
Although bark beetles are generally regarded as forest pests, only a very small proportion of the approximately 5,800 species in the world (54) can kill healthy trees. The few aggressive species play important ecological and economic roles, particularly in temperate conifer forests. In North America, they have been estimated to be responsible for more tree mortality than all other natural factors combined (53). The majority of the bark beetles are nonaggressive and colonize only dead trees (i.e., saprophagic species) or severely stressed or dying trees (i.e., facultatively parasitic species [40]).

In this study, we compare the phytopathogenicity of four bluestain fungi associated with different bark beetles that range from aggressive to saprophagic. All beetle species colonize a common host, Norway spruce (Picea abies (L.) H. Karst.). Our objective was to determine if fungi vectored by the less aggressive beetles could invade healthy trees and to test the hypothesis that aggressive bark beetles are associated with more pathogenic fungi than nonaggressive species.

\section{MATERIALS AND METHODS}

Fungal species. Norway spruce trees were mass-inoculated with the following four fungi: Ceratocystis polonica (Siem.) C. Moreau, Ophiostoma piceae (Münch) H. Sydow \& P. Sydow, an apparent Ambrosiella sp., and a sterile fungus with dark mycelium (Dark sterile sp. A). A different isolate of each fungus was used in 1995 and 1996 (Table 1). The fungi were originally isolated in a survey of the fungal associates of five species of bark beetles colonizing Norway spruce (25). The four fungi were chosen from all the different fungi that are associated with these bark beetles because they are consistent associates of one or more of the beetles and because their pathogenicity to Norway spruce has not been tested before. The pathogenicity of the other major fungal associates of these bark beetles has been tested previously (45; H. Solheim, unpublished data). 
C. polonica is the most important fungal associate of Ips typographus L. In Norway, 35 to $94 \%$ of the beetles carry this fungus (14, 25,44,46). C. polonica has also been isolated consistently from $I$. duplicatus $(25)$, and its likely synonym $C$. laricicola $(19,50)$ has been isolated in low frequencies from I. cembrae in Scotland and Japan (41). O. piceae is a common sapstain fungus of lumber in both Europe and North America (43). It has been isolated from I. typographus, Pityogenes chalcographus, Hylurgops palliatus, and several other species of Scolytidae, Curculionidae, and Nitidulidae, and is, thus, nonspecific with respect to vectors $(25,31,44)$. In a recent study in Norway, O. piceae was isolated from 31 and $17 \%$ of I. typographus and $H$. palliatus individuals, respectively (25). Dark sterile sp. A and the Ambrosiella sp. have been isolated from a high percentage of individuals of the nonaggressive bark beetles $\mathrm{H}$. palliatus (69\%) and Polygraphus poligraphus (28\%), respectively (25).

Inoculation and sampling. Sixty Norway spruce trees of similar size and age were selected from a stand in As, Norway (Tables 2 and 3). Eight trees in 1995 and four trees in 1996 were randomly assigned to each of the four fungi and to the control. Trees were massinoculated at a density of 400 inoculations per $\mathrm{m}^{2}$ in a $1.2-\mathrm{m}$-wide band from about 0.8 to $2 \mathrm{~m}$ above ground on 5 to 7 June 1995 and 15 to 16 July 1996 . Trees were inoculated by removing a bark plug with a 5-mm cork borer, inserting inoculum in the wound, and replacing the bark plug. Inoculum consisted of actively growing mycelium of the four fungi on malt agar (2\% malt and $1.5 \%$ agar) and sterile malt agar as a control. Fourteen weeks after inoculation, we measured resin flow from inoculation wounds by determining the proportion of a random sample of 90 to 100 inoculation points per tree with resin flow longer than $3 \mathrm{~mm}$. At the same time, we removed the outer bark over six of the uppermost and six of the lowermost inoculation sites on each tree and measured maximum width and length of the necrosis surrounding each inoculation point. Necrosis length was measured from the center of the inoculation wound and in one direction away from the inoculated band. This was done because necroses often coalesce in the inoculation band on trees inoculated with C. polonica.

The trees were felled 15 weeks after inoculation. We measured tree height growth for the previous three growth seasons, length of green crown, and total tree height. The central $0.6 \mathrm{~m}$ of each inoculated stem section was removed and taken to the laboratory, where it was processed within $24 \mathrm{~h}$. From the $0.6-\mathrm{m}$ bolts, we cut two 5-mm-thick stem disks about $0.1 \mathrm{~m}$ from the upper and lower end. Based on translucency, we outlined the sapwood-heartwood border, the border between desiccated and apparently healthy sap-

TABLE 1. Isolate number and collection information for the four blue-stain fungi inoculated in Norway spruce in 1995 and 1996

\begin{tabular}{|c|c|c|c|c|}
\hline Species & Isolate no. ${ }^{\mathrm{z}}$ & Inoculated & Collected & Substrate \\
\hline \multirow[t]{2}{*}{ Ceratocystis polonica } & $93-208 / 115$ & 1995 & 1993, Akershus, Norway & Picea abies, Polygraphus poligraphus \\
\hline & $94-169 / 13$ & 1996 & 1994, Akershus, Norway & Picea abies, Ips typographus \\
\hline \multirow{2}{*}{ Ophiostoma piceae } & $94-169 / 56$ & 1995 & 1994, Akershus, Norway & Picea abies, Ips typographus \\
\hline & $96-65 / 27$ & 1996 & 1996, Akershus, Norway & Hylurgops palliatus \\
\hline \multirow[t]{2}{*}{ Ambrosiella sp. } & $93-208 / 44$ & 1995 & 1993, Akershus, Norway & Picea abies, Polygraphus poligraphus \\
\hline & $94-176 \mathrm{~B} / 4$ & 1996 & 1994, Akershus, Norway & Polygraphus poligraphus \\
\hline \multirow[t]{2}{*}{ Dark sterile sp. A } & $94-166 / 39$ & 1995 & 1994, Akershus, Norway & Picea abies, Hylurgops palliatus \\
\hline & $94-166 / 25$ & 1996 & 1994, Akershus, Norway & Picea abies, Hylurgops palliatus \\
\hline
\end{tabular}

${ }^{\mathrm{z}}$ Numbers refer to the reference collection at Norwegian Forest Research Institute.

TABLE 2. Characteristics of Norway spruce trees mass-inoculated with four different fungi or sterile agar control in 1995

\begin{tabular}{|c|c|c|c|c|c|c|c|c|c|}
\hline \multirow[b]{2}{*}{ Treatment } & \multirow[b]{2}{*}{$\mathrm{DBH}^{\mathrm{w}}(\mathrm{cm})$} & \multirow[b]{2}{*}{ Tree age } & \multirow[b]{2}{*}{ Tree height $(\mathrm{m})$} & \multirow[b]{2}{*}{ Crown length (m) } & \multicolumn{3}{|c|}{ Height growth $(\mathrm{cm})$} & \multicolumn{2}{|c|}{ Annual ring width (mm) } \\
\hline & & & & & $1995^{x}$ & $1994^{x}$ & $1993^{x}$ & $1995^{y}$ & $(1992-1994) / 3$ \\
\hline Ceratocystis polonica & 18.3 & 39.8 & 18.2 & 11.2 & 22.2 & 17.3 & 15.6 & $0.53 \mathrm{a}$ & 0.95 \\
\hline Ophiostoma piceae & 17.6 & 41.9 & 18.1 & 10.4 & 28.2 & 17.4 & 15.6 & $1.11 \mathrm{c}$ & 0.69 \\
\hline Ambrosiella sp. & 17.5 & 43.1 & 19.0 & 10.9 & 21.6 & 13.6 & 18.4 & $1.01 \mathrm{c}$ & 0.70 \\
\hline Dark sterile sp. A & 17.7 & 41.5 & 17.7 & 12.0 & 18.9 & 12.4 & 14.1 & $0.88 \mathrm{bc}$ & 0.82 \\
\hline Control & 17.7 & 40.5 & 18.9 & 11.6 & 25.1 & 18.0 & 12.3 & $0.70 \mathrm{ab}$ & 0.63 \\
\hline$F$ value $^{\mathrm{z}}$ & 0.89 & 1.02 & 1.00 & 0.50 & 1.13 & 2.13 & 1.04 & 4.82 & 1.51 \\
\hline$R^{2}$ & 0.09 & 0.10 & 0.10 & 0.05 & 0.12 & 0.20 & 0.11 & 0.36 & 0.15 \\
\hline$P$ & 0.48 & 0.41 & 0.42 & 0.74 & 0.36 & 0.10 & 0.40 & 0.004 & 0.22 \\
\hline
\end{tabular}

${ }^{w}$ Diameter at breast height.

x Data were transformed $\left(\log _{10} y+1\right)$ before analysis; nontransformed values are reported.

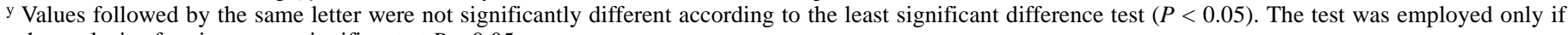
the analysis of variance was significant at $P<0.05$.

${ }^{\mathrm{z}}$ Degrees of freedom $(\mathrm{df})=4,35$ for all tests, except for height growth in which $\mathrm{df}=4,34$.

TABLE 3. Characteristics of Norway spruce trees mass-inoculated with four different fungi or sterile agar control in 1996

\begin{tabular}{|c|c|c|c|c|c|c|c|c|c|}
\hline \multirow[b]{2}{*}{ Treatment } & \multirow[b]{2}{*}{$\mathrm{DBH}^{\mathrm{x}}(\mathrm{cm})$} & \multirow[b]{2}{*}{ Tree age } & \multirow[b]{2}{*}{ Tree height (m) } & \multirow[b]{2}{*}{ Crown length $(\mathrm{m})$} & \multicolumn{3}{|c|}{ Height growth (cm) } & \multicolumn{2}{|c|}{ Annual ring width (mm) } \\
\hline & & & & & $1996^{y}$ & $1995^{\mathrm{y}}$ & $1994^{y}$ & 1996 & $(1993-1995) / 3$ \\
\hline Ceratocystis polonica & 16.60 & 42.3 & 17.9 & 9.8 & 19.3 & 19.0 & 15.8 & 0.58 & 0.50 \\
\hline Ophiostoma piceae & 17.01 & 40.5 & 17.6 & 10.0 & 26.8 & 24.0 & 18.8 & 1.03 & 0.84 \\
\hline Ambrosiella sp. & 16.40 & 42.5 & 17.6 & 9.0 & 27.0 & 16.5 & 15.3 & 0.54 & 0.66 \\
\hline Dark sterile sp. A & 17.49 & 43.0 & 18.6 & 10.0 & 21.0 & 16.0 & 13.0 & 0.50 & 0.62 \\
\hline Control & 16.31 & 41.8 & 17.2 & 11.7 & 34.8 & 25.3 & 22.0 & 0.71 & 0.86 \\
\hline$F$ value $^{\mathrm{z}}$ & 1.38 & 0.38 & 0.25 & 0.82 & 0.70 & 1.48 & 1.70 & 1.34 & 1.35 \\
\hline$R^{2}$ & 0.27 & 0.09 & 0.06 & 0.18 & 0.17 & 0.30 & 0.33 & 0.28 & 0.28 \\
\hline$P$ & 0.29 & 0.82 & 0.91 & 0.53 & 0.61 & 0.26 & 0.21 & 0.30 & 0.30 \\
\hline
\end{tabular}

x Diameter at breast height.

y Data were transformed $\left(\log _{10} y+1\right)$ before analysis; nontransformed values are reported.

${ }^{\mathrm{z}}$ Degrees of freedom $=4,14$ for all tests. 
wood, and the border between blue-stained and desiccated sapwood on the upper surface of each disk (10). The surface area of heartwood, total sapwood, and blue-stained, desiccated, and normal sapwood was later determined with a computer-connected planimeter (Ultima: GTCO Corporation, Columbia, MD; "Blåveden" software: G. Fjone, Nisk, Ås, Norway). Along the disk circumference, we measured the proportion of dead and live cambium. On the lower disk, taken about $1.2 \mathrm{~m}$ above ground, we estimated tree age and measured annual ring width for the last 4 years of growth along four radii. On each $0.6-\mathrm{m}$ bolt, we removed the outer bark and traced all phloem necroses in a $0.062-\mathrm{m}^{2}$ area onto clear acetate. Total area of dead phloem was later determined from the acetate sheets with a planimeter. Fungi were reisolated from phloem and sapwood around three inoculation points on each tree.

Data analysis. For each year, length and width of individual necrotic zones, percent dead phloem, percent dead cambium, and percent blue-stained and desiccated sapwood area were subjected to one-factor analysis of variance (ANOVA). The ANOVA was unbalanced for the 1996 data, since one tree inoculated with the Ambrosiella sp. was attacked by bark beetles and had to be discarded. Tree characteristics such as age, height growth, and annual ring width were also subjected to one-factor ANOVA. For height growth in 1995, the ANOVA was unbalanced, since one tree with a broken top (inoculated with $O$. piceae) had to be discarded. Mean values for each tree were used in all analyses.

Some data were transformed before ANOVA (Tables 2 to 5) to correct for unequal variances and departures from normality as indicated by graphical analysis of residuals (30). If treatments were significantly different $(P<0.05)$, means were separated using the least significant difference test at $P<0.05$ (30). The nontrans- formed means are reported. All statistical analyses were performed with the general linear models procedure of SAS (SAS Institute Inc., Cary, NC).

\section{RESULTS}

In 1995, C. polonica was much more pathogenic than the other fungi based on all criteria of fungal pathogenicity (Table 4). It was the only fungus that caused blue-stain, and it induced more sapwood desiccation, 21 times more dead cambium area, 11 times more dead phloem area, and twice as wide and five times longer phloem necrotic zones than any other fungus (Table 4). Two trees inoculated with $C$. polonica in 1995 had less than $2 \%$ functioning sapwood, and four others had 14 to $25 \%$ functioning sapwood. Except for resin exudation and shallow depressions on the bark around inoculations with C. polonica in 1995 and 1996 and the Ambrosiella sp. in 1996, the trees showed no visible external symptoms of infection. In 1995, O. piceae, the Ambrosiella sp., and Dark sterile sp. A did not differ significantly in any criterion of fungal pathogenicity (Table 4). They were all significantly different from the control, except for percent dead cambium and width of necrosis (Table 4). All fungi induced much more sapwood desiccation than the control (Table 4). There were no significant differences in resin exudation among trees inoculated with different fungi, but control trees exuded significantly less resin than inoculated trees (Table 4).

In 1996, C. polonica generally caused less extensive symptoms than in 1995 and the differences in pathogenicity between the four inoculated fungi were smaller (Table 5). In particular, inoculation with the Ambrosiella sp. and C. polonica induced comparable

TABLE 4. Indices of fungal success 15 weeks after mass inoculation of four blue-stain fungi and sterile agar in Norway spruce, 1995 experiment ${ }^{\mathrm{t}}$

\begin{tabular}{|c|c|c|c|c|c|c|c|}
\hline \multirow[b]{2}{*}{ Treatment } & \multicolumn{2}{|c|}{ Phloem necrosis $(\mathrm{mm})$} & \multicolumn{2}{|c|}{$\%$ Sapwood area ${ }^{\mathrm{u}}$} & \multirow[b]{2}{*}{$\%$ Dead phloem ${ }^{\mathrm{x}}$} & \multirow[b]{2}{*}{$\%$ Dead cambium $^{\mathrm{x}}$} & \multirow[b]{2}{*}{ Resin flow ${ }^{y}$} \\
\hline & Length $^{\mathrm{v}, \mathrm{w}}$ & Width $^{\mathrm{W}}$ & Blue-stained & Blue-stained and desiccated ${ }^{\mathrm{x}}$ & & & \\
\hline Ceratocystis polonica & $65.4 \mathrm{a}$ & $17.7 \mathrm{a}$ & 56.3 & $77.9 \mathrm{a}$ & $80.3 \mathrm{a}$ & $71.9 \mathrm{a}$ & $54.0 \mathrm{a}$ \\
\hline Ophiostoma piceae & $10.1 \mathrm{~b}$ & $8.8 \mathrm{~b}$ & 0.0 & $16.0 \mathrm{~b}$ & $5.9 \mathrm{~b}$ & $3.1 \mathrm{~b}$ & $40.0 \mathrm{a}$ \\
\hline Ambrosiella sp. & $13.1 \mathrm{~b}$ & $8.9 \mathrm{~b}$ & 0.0 & $12.5 \mathrm{~b}$ & $7.1 \mathrm{~b}$ & $3.4 \mathrm{~b}$ & $53.0 \mathrm{a}$ \\
\hline Dark sterile sp. A & $12.2 \mathrm{~b}$ & $10.2 \mathrm{~b}$ & 0.0 & $15.2 \mathrm{~b}$ & $7.3 \mathrm{~b}$ & $3.2 \mathrm{~b}$ & $49.0 \mathrm{a}$ \\
\hline Control & $6.8 \mathrm{c}$ & $9.5 \mathrm{~b}$ & 0.0 & $1.6 \mathrm{c}$ & $4.0 \mathrm{c}$ & $1.8 \mathrm{~b}$ & $22.0 \mathrm{~b}$ \\
\hline$F$ ratio $^{z}$ & 75.29 & 21.06 & $\ldots$ & 35.35 & 152.37 & 119.62 & 5.54 \\
\hline$R^{2}$ & 0.90 & 0.71 & $\ldots$ & 0.80 & 0.95 & 0.93 & 0.39 \\
\hline$P$ & 0.0001 & 0.0001 & $\ldots$ & 0.0001 & 0.0001 & 0.0001 & 0.002 \\
\hline
\end{tabular}

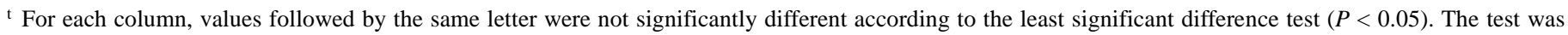
employed only if analysis of variance was significant at $P<0.05$.

u Percentage of cross-sectional sapwood area on a stem disk taken inside the mass-inoculated part of the bole.

${ }^{v}$ Necroses were measured in only one direction from the point of inoculation.

${ }^{w}$ Data were transformed $\left(\log _{10} y+1\right)$ before analysis; nontransformed values are reported.

$x$ Data were transformed (arcsine $\sqrt{y}$ ) before analysis; nontransformed values are reported.

y Percentage of 90 to 100 inoculation points per tree with external resin flow longer than $3 \mathrm{~mm}$.

${ }^{\mathrm{z}}$ Degrees of freedom $=4,35$ for all tests.

TABLE 5. Indices of fungal success 15 weeks after mass inoculation of four blue-stain fungi and sterile agar in Norway spruce, 1996 experiment ${ }^{\mathrm{w}}$

\begin{tabular}{|c|c|c|c|c|c|c|}
\hline \multirow[b]{2}{*}{ Treatment } & \multicolumn{2}{|c|}{ Phloem necrosis (mm) } & \multirow[b]{2}{*}{$\%$ Desiccated sapwood area ${ }^{y}$} & \multirow[b]{2}{*}{$\%$ Dead phloem ${ }^{y}$} & \multirow[b]{2}{*}{$\%$ Dead cambium ${ }^{\mathrm{y}}$} & \multirow[b]{2}{*}{ Resin flow } \\
\hline & Length $^{\mathrm{x}}$ & Width $^{\mathrm{x}}$ & & & & \\
\hline Ceratocystis polonica & $42.52 \mathrm{a}$ & $22.31 \mathrm{a}$ & $53.2 \mathrm{a}$ & $47.2 \mathrm{a}$ & $42.8 \mathrm{a}$ & $87.2 \mathrm{a}$ \\
\hline Ophiostoma piceae & $13.48 \mathrm{~b}$ & $11.19 \mathrm{~b}$ & $16.1 \mathrm{bc}$ & $7.4 \mathrm{~b}$ & $8.6 \mathrm{~b}$ & $65.5 \mathrm{~b}$ \\
\hline Ambrosiella sp. & $34.08 \mathrm{a}$ & $19.39 \mathrm{a}$ & $27.5 \mathrm{ab}$ & $53.2 \mathrm{a}$ & $39.3 \mathrm{a}$ & $74.2 \mathrm{~b}$ \\
\hline Dark sterile sp. A & $8.23 \mathrm{bc}$ & $9.44 \mathrm{~b}$ & $3.5 \mathrm{c}$ & $5.0 \mathrm{~b}$ & $7.3 \mathrm{~b}$ & $43.8 \mathrm{c}$ \\
\hline Control & $7.33 \mathrm{c}$ & $9.79 \mathrm{~b}$ & $8.3 \mathrm{bc}$ & $4.2 \mathrm{~b}$ & $3.4 \mathrm{~b}$ & $40.4 \mathrm{c}$ \\
\hline$F$ ratio $^{z}$ & 16.62 & 9.28 & 6.02 & 15.11 & 9.34 & 20.91 \\
\hline$R^{2}$ & 0.83 & 0.73 & 0.67 & 0.81 & 0.73 & 0.86 \\
\hline$P$ & 0.0001 & 0.0007 & 0.007 & 0.0001 & 0.0007 & 0.0001 \\
\hline
\end{tabular}

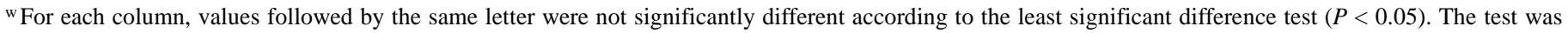
employed only if analysis of variance was significant at $P<0.05$.

${ }^{x}$ Data were transformed $\left(\log _{10} y+1\right)$ before analysis; nontransformed values are reported.

y Data were transformed (arcsine $\sqrt{y}$ ) before analysis; nontransformed values are reported.

${ }^{\mathrm{z}}$ Degrees of freedom $=4,14$ for all tests. 
symptoms, and these two fungi generally induced significantly more extensive symptoms than the other two fungi. In 1996, Dark sterile sp. A. and $O$. piceae did not differ significantly from the control for most criteria of fungal pathogenicity (Table 5). None of the fungi inoculated in 1996 caused any sapwood blue-stain. Trees inoculated with $C$. polonica in 1996 exuded significantly more resin than the other trees (Table 5). For all treatments except Dark sterile sp. A, resin exudation was stronger in 1996 compared with 1995. Trees inoculated with $O$. piceae and the Ambrosiella sp. in 1996 generally had more extensive symptoms in the phloem and cambium than the trees inoculated in 1995.

The reisolations yielded high frequencies of most of the inoculated fungi both years (42 to 100\% of inoculations positive). Experimental fungi were normally not isolated from sites other than where they had been inoculated, except for $O$. piceae, which was reisolated occasionally from control trees and trees inoculated with Dark sterile sp. A in 1996. O. piceae was the only fungus that was reisolated from all inoculations, but most of the inoculations with the other fungi probably resulted in successful colonization, as indicated by the presence of phloem necroses around most inoculation sites. In 1995, C. polonica was generally reisolated further into the sapwood than the other fungi.

There were no significant differences among trees allocated to the different treatments with respect to any tree characteristics in either 1995 or 1996 (Tables 2 and 3). The only exception was that trees inoculated with $C$. polonica in 1995 had very narrow growth rings that year (Table 2). When annual ring width for 1995 was divided by the average for the years 1992 to 1994, C. polonica had a value of only 55\%, compared with 106 to $160 \%$ for the other treatments $\left(P<0.0008, F=6.17, R^{2}=0.42\right)$. In 1996, the corresponding figures were $112 \%$ versus 75 to $129 \%(P=0.21, F=$ $1.35, R^{2}=0.32$ ). Trees inoculated in 1995 and 1996 were generally very similar in size and growth, although the trees inoculated in 1996 were slightly smaller (Tables 2 and 3).

\section{DISCUSSION}

The pathogenicity of $C$. polonica that was demonstrated in the current study is consistent with results from previous mass inoculations of Norway spruce with this fungus $(7,8,23,45)$. In the 1996 test, the Ambrosiella sp. was moderately pathogenic to Norway spruce. This fungus is associated with the facultatively parasitic Polygraphus poligraphus (25), which can colonize stressed and weakened Norway spruce when its population level is high. $O$. piceae and Dark sterile sp. A are associated with various nonaggressive bark beetles colonizing Norway spruce (25) and are not particularly pathogenic. Other fungi that have been isolated from these and other bark beetles colonizing Norway spruce are either saprophagous (25) or have been shown to be relatively nonpathogenic in previous mass-inoculation experiments (45; H. Solheim, unpublished data). One exception is $O$. penicillatum, associated with the aggressive bark beetle I. typographus and the facultatively parasitic I. duplicatus, which is moderately pathogenic to Norway spruce (45). These results are consistent with the hypothesis that aggressive bark beetle species vector virulent fungi that may aid them in killing trees, but it appears that some nonaggressive bark beetles also may vector pathogenic fungi.

Nonaggressive bark beetles that attack the roots or base of dead, weakened, or healthy trees vector the pathogenic blue-stain fungus Leptographium terebrantis (e.g., D. valens, D. terebrans, and Hylastes porculus $[17,24]$ ). These beetles do not engage in mass attacks, but colonize parts of the tree with high oleoresin pressure and water content and correspondingly low oxygen levels. Pathogenic blue-stain fungi are probably well adapted to colonize such environments (47), and the beetles may be dependent on a fast-growing pathogen to colonize such tissue (17). The facultatively parasitic $I$. duplicatus is consistently associated with $C$. polonica in Norway (25). However, this beetle may be more aggressive than previously recognized, as it has recently killed Norway spruce over large areas in Central Europe (36).

C. polonica killed a large proportion of the phloem, cambium, and sapwood of the trees inoculated in 1995, and most of the trees inoculated with this fungus would probably have developed foliar symptoms if we had delayed harvesting. We did not delay harvesting because foliar symptoms may not occur until the growing season after inoculation and, before then, the trees are likely to be attacked by secondary bark beetles (23). In some previous mass inoculations of Norway spruce with $C$. polonica, the foliage turned brown and started to drop 10 to 14 weeks after inoculation $(7,8)$. The higher inoculation densities used in those studies may have been responsible for the earlier appearance of symptoms. Tree age and timing of inoculation may also affect the pathogenicity of $C$. polonica $(7,9,22)$.

$C$. polonica was the only fungus that reduced radial growth of the trees during the season of inoculation relative to three previous seasons. This occurred in 1995, the only season when trees were seriously affected by any treatment. Reduced radial growth after mass inoculation has been observed previously in Norway spruce inoculated with $C$. polonica $(7,9)$ and in Sitka spruce $(P$. sitchensis) inoculated with $C$. rufipenni (48). The reduced growth suggests that trees inoculated with $C$. polonica in 1995 may have allocated more resources to defense and less to growth than trees inoculated with other fungi or the control (9). Growth may also have been reduced as a result of water stress (9) following fungal colonization of the sapwood. Inoculation with $C$. polonica did not affect height growth in either year (Tables 2 and 3), contrary to the finding of Christiansen (7). This discrepancy may be a result of the timing of the inoculations. Our inoculations were done 2 and 8 weeks later than Christiansen's, and it is possible that the trees had completed most of their height growth before they were seriously stressed by $C$. polonica. When Sitka spruce was mass-inoculated with $C$. rufipenni partway through the growing season, there was no reduction in height growth (48). Height growth is generally less affected by stress than radial growth (27).

C. polonica produced more and deeper stain/desiccation and was reisolated further into the sapwood than the other fungi. This is consistent with previous studies that have shown $C$. polonica to be at the leading edge of fungal penetration all the way to the heartwood in Norway spruce attacked by I. typographus (46). The ability to invade fresh sapwood may be the most important characteristic of the pathogenic associates of aggressive bark beetles (34).

$O$. piceae is regarded as a weak bark pathogen (5). Its pathogenicity to Norway spruce has not been tested previously, but, based on phloem necrosis length, it was considered to be relatively pathogenic when inoculated into mature white spruce $(P$. glauca) $(42)$ and moderately pathogenic to seedlings of eastern white pine (Pinus strobus) (31). O. piceae seemed to be less pathogenic to Norway spruce in the current study. Inoculation with O. piceae, the Ambrosiella $\mathrm{sp}$., and Dark sterile sp. A resulted in 4.0 to $28.0 \%$ desiccated sapwood (Tables 4 and 5). The pathological significance of this sapwood desiccation is uncertain. It did not seem to affect stem growth, since there were no significant differences in annual ring width in the season of inoculation between the three fungi and the control. In fact, trees inoculated with $O$. piceae and the Ambrosiella sp., the fungi that caused the largest proportion of desiccated sapwood, had the largest basal area increment of all trees in 1995 (175 and 166\%, respectively, of the average during 1992 to 1994 ). O. piceae, the Ambrosiella sp., and Dark sterile sp. A induced much more sapwood desiccation in Norway spruce than several nonpathogenic blue-stain fungi associated with I. typographus (45).

The higher pathogenicity observed for the Ambrosiella sp. and, to some extent, for $O$. piceae in 1996 compared with 1995 may have been caused by year-to-year variation in experimental conditions, different timing of inoculation relative to host phenology, or different virulence of different fungal isolates. Inoculations were made 6 weeks later in 1996 than in 1995, and mean temperature 
the first month after inoculation was almost $2^{\circ} \mathrm{C}$ higher. The higher temperature may have had a positive effect on the fungi and increased their ability to colonize host tissues. This agrees with an earlier study in Norway spruce (22) that found trees to be more resistant to infection by $C$. polonica in spring/early summer (May to June) than later in the growth season. Thus, the higher pathogenicity observed for the Ambrosiella sp. and O. piceae in 1996 may have been a combined effect of using more virulent fungal isolates in 1996 and inoculating the trees later in the growth season.

For $C$. polonica, different virulence between isolates seems to be the most likely explanation for the lower pathogenicity observed in 1996, since the late inoculation date should have led to increased virulence in this season (22). Lower virulence of the isolate used in 1996 was also apparent when the two isolates were inoculated in seedlings and logs of Norway spruce (H. Solheim and P. Krokene, unpublished data). Although the isolate used in 1996 was less virulent than the isolate used in 1995, it induced equally extensive host symptoms as two isolates used in a previous massinoculation experiment (45). Lower virulence of the isolate used in 1996 may explain the lack of any blue-staining in trees inoculated in 1996. Staining occurs when the mycelium has reached a certain density in the sapwood (52), and it is likely that the $C$. polonica isolate used in 1996 was unable to colonize the sapwood sufficiently to cause blue-stain.

The inoculation density (400 inoculations per $\mathrm{m}^{2}$ ) that was used in this study is equivalent to a high natural attack density for $I$. typographus, which normally colonizes trees at 100 to 400 attacks per $\mathrm{m}^{2}(7,51)$. However, attack densities of up to 1,800 per $\mathrm{m}^{2}$ have been recorded (51). Because one beetle gallery is probably a more severe challenge to the tree's defenses than one inoculation $(23,38)$ and most individuals of I. typographus carry C. polonica $(14,25)$, attack by beetles is probably more detrimental to the trees than our inoculations. Furthermore, a natural mass attack extends over a large part of the stem, while our inoculations were restricted to a $1.2-\mathrm{m}$-long segment. Total number of inoculations is probably more important than the inoculation pattern (7).

The relative importance of the fungus and the beetles in the killing of the host has been the subject of a long and continuing debate $(6,11,17,21)$. I. typographus and most other aggressive bark beetles seem to be associated with at least one pathogenic fungus, although there is significant variation in the pathogenicity of the fungi associated with different beetles $(18,35,52)$. For example, the associates of I. typographus, Dendroctonus ponderosae, and $D$. rufipennis seem to be more pathogenic than those of $D$. frontalis and $D$. brevicomis $(18,48)$. D. frontalis and D. brevicomis may also have a looser association with their pathogenic fungus, as instances of successful mass attacks with little or no visible sign of blue-stain fungi have been recorded (6). Thus, the question of whether association with pathogenic fungi is essential to overwhelm host defenses for all aggressive bark beetles remains unresolved (33). In some bark beetle-blue-stain fungi-host tree interactions, the fungi seem to play an important role in tree killing, while, in other systems, the role of the fungi is more uncertain. However, since all aggressive bark beetles are associated with more or less pathogenic fungi, the tree will always face an attacking beetle-fungus complex that probably acts synergistically to overwhelm host defenses $(39,52)$.

The most important advantage aggressive bark beetles gain from a pathogenic fungus may be that the fungus prevents the host from expressing its potential resistance against attack. For example, multiple inoculations with $C$. polonica reduces the quantity of monoterpenes that accumulates at each wound site (7). Fungi may also prevent the host from recovering after the initial attack and killing the developing brood with secondary resinosis $(2,12)$. The fungus probably interferes with the water relations of the tree, either directly through hyphal growth into the water conducting vessels, indirectly through the production of toxins (20), or through induction of tracheid cavitation (26).
The conditions under which association with pathogenic fungi are favorable to the beetle may be limited, however, and may be restricted to periods with high beetle activity (32). When the beetles colonize dead and dying trees during nonepidemic periods, the fungus may act as a competitor for the limited nutrients in the phloem (2). To speculate further, the benefits accrued to the beetles by an association with pathogenic fungi may be less during nonepidemic periods, when it is less likely that a mass attack can be initiated. This could conceivably select against association with pathogenic fungi in aggressive species during nonepidemic periods and against association at any time for nonaggressive species.

\section{ACKNOWLEDGMENTS}

We thank the Agricultural University of Norway for providing experimental trees, and E. Christiansen for valuable support during this study. The fungal cultures were provided from the culture collection of Norwegian Forest Research Institute. This work was supported financially by a grant to P. Krokene from the Research Council of Norway. We thank K. Anthonisen, E. Børresen, M. Christiansen, Ø. Edvardsen, M. Krekling, C. Krokene, O. Olsen, I. Ryen, and J. Tjelle for their help in the lab or field. We thank E. Christiansen, L. Kirkendall, D. Ross, and two anonymous referees for critical reviews of the manuscript.

\section{LITERATURE CITED}

1. Barbosa, P., Krischik, V. A., and Jones, C. G., eds. 1991. Microbial Mediation of Plant-Herbivore Interactions. John Wiley \& Sons, New York.

2. Barras, S. J. 1970. Antagonism between Dendroctonus frontalis and the fungus Ceratocystis minor. Ann. Entomol. Soc. Am. 63:1187-1190.

3. Beaver, R. A. 1989. Insect-fungus relationships in the bark and ambrosia beetles. Pages 119-143 in: Insect-Fungus Interactions. N. Wilding, N. M. Collins, P. M. Hammond, and J. F. Webber, eds. Academic Press, San Diego, CA.

4. Brand, J. M., Bracke, J. W., Britton, L. N., Markovetz, A. J., and Barras, S. J. 1976. Bark beetle pheromones: Production of verbenone by a mycangial fungus of Dendroctonus frontalis. J. Chem. Ecol. 2:195-199.

5. Brasier, C. M., and Kirk, S. A. 1993. Sibling species within Ophiostoma piceae. Mycol. Res. 97:811-816.

6. Bridges, J. R., Nettleton, W. A., and Connor, M. D. 1985. Southern pine beetle (Coleoptera: Scolytidae) infestations without the bluestain fungus, Ceratocystis minor. J. Econ. Entomol. 78:325-327.

7. Christiansen, E. 1985. Ceratocystis polonica inoculated in Norway spruce: Blue-staining in relation to inoculum density, resinosis and tree growth. Eur. J. For. Pathol. 15:160-167.

8. Christiansen, E. 1985. Ips/Ceratocystis infection of Norway spruce: What is a deadly dosage? Z. Angew. Entomol. 99:6-11.

9. Christiansen, E. 1992. After-effects of drought did not predispose young Picea abies to infection by the bark beetle-transmitted blue-stain fungus Ophiostoma polonicum. Scand. J. For. Res. 7:557-569.

10. Christiansen, E., Waring, R. H., and Berryman, A. A. 1987. Resistance of conifers to bark beetle attack: Searching for general relationships. For. Ecol. Manage. 22:89-106.

11. Craighead, F. C. 1928. Interrelation of tree-killing bark beetles (Dendroctonus) and blue stains. J. For. 26:886-887.

12. Fares, Y., Magnusen, C. E., Doraiswamy, P. C., and Sharpe, P. J. H. 1980. Dynamics of bark beetle-fungus symbiosis. II. Pine tree drying model. Pages 61-74 in: Modeling Southern Pine Beetle Populations. F. M. Stephen, J. L. Searcy, and G. D. Hertel, eds. U.S. Dep. Agric. For. Serv. Sci. Educ. Admin. Tech. Bull. 1630.

13. Francke-Grosmann, H. 1967. Ectosymbiosis in wood-inhabiting insects. Pages 141-205 in: Symbiosis. S. M. Henry, ed. Academic Press, New York.

14. Furniss, M. M., Solheim, H., and Christiansen, E. 1990. Transmission of blue-stain fungi by Ips typographus (Coleoptera: Scolytidae) in Norway spruce. Ann. Entomol. Soc. Am. 83:712-716.

15. Goldhammer, D. S., Stephen, F. M., and Paine, T. D. 1990. The effect of fungi Ceratocystis minor (Hedgecock) Hunt, Ceratocystis minor (Hedgecock) var. barrasii and SJB 122 on reproduction of the southern pine beetle, Dendroctonus frontalis Zimmermann (Coleoptera: Scolytidae). Can. Entomol. 122:407-418.

16. Harrington, T. C. 1988. Leptographium species, their distributions, hosts and insect vectors. Pages 1-39 in: Leptographium Root Diseases in Conifers. T. C. Harrington and F. W. Cobb, Jr., eds. The American Phytopathological Society, St. Paul, MN.

17. Harrington, T. C. 1993. Biology and taxonomy of fungi associated with bark beetles. Pages 37-58 in: Beetle-Pathogen Interactions in Conifer 
Forests. T. D. Schowalter and G. M. Filip, eds. Academic Press, London. 18. Harrington, T. C. 1993. Diseases of conifers caused by species of Ophiostoma and Leptographium. Pages 161-172 in: Ceratocystis and Ophiostoma. Taxonomy, Ecology, and Pathogenicity. M. J. Wingfield, K. A. Seifert, and J. F. Webber, eds. The American Phytopathological Society, St. Paul, MN.

19. Harrington, T. C., Steimel, J. P., Wingfield, M. J., and Kile, G. A. 1996. Isozyme variation and species delimitation in the Ceratocystis coerulescens complex. Mycologia 88:104-113.

20. Hemingway, R. W., McGraw, G. W., and Barras, S. J. 1977. Polyphenols in Ceratocystis minor infected Pinus taeda: Fungal metabolites, phloem and xylem phenols. J. Agric. Food Chem. 25:717-722.

21. Hobson, K. R., Parmeter, J. R., Jr., and Wood, D. L. 1994. The role of fungi vectored by Dendroctonus brevicomis LeConte (Coleoptera: Scolytidae) in occlusion of ponderosa pine xylem. Can. Entomol. 126:277-282.

22. Horntvedt, R. 1988. Resistance of Picea abies to Ips typographus: Tree response to monthly inoculations with Ophiostoma polonicum, a beetle transmitted blue-stain fungus. Scand. J. For. Res. 3:107-114.

23. Horntvedt, R., Christiansen, E., Solheim, H., and Wang, S. 1983. Artificial inoculation with Ips typographus-associated blue-stain fungi can kill healthy Norway spruce trees. Medd. Nor. Inst. Skogforsk. 38:1-20.

24. Klepzig, K. D., Smalley, E. B., and Raffa, K. F. 1995. Dendroctonus valens and Hylastes porculus (Coleoptera: Scolytidae): Vectors of pathogenic fungi (Ophiostomatales) associated with red pine decline disease. Great Lakes Entomol. 28:81-87.

25. Krokene, P., and Solheim, H. 1996. Fungal associates of five bark beetle species colonizing Norway spruce. Can. J. For. Res. 26:2115-2122.

26. Kuroda, K. 1991. Mechanism of cavitation development in the pine wilt disease. Eur. J. For. Pathol. 21:82-89.

27. Långström, B., and Hellqvist, C. 1991. Effects of different pruning regimes on growth and sapwood area of Scots pine. For. Ecol. Manage. 44:239-254

28. Malloch, D., and Blackwell, M. 1993. Dispersal biology of the Ophiostomatoid fungi. Pages 195-206 in: Ceratocystis and Ophiostoma. Taxonomy, Ecology, and Pathogenicity. M. J. Wingfield, K. A. Seifert, and J. F. Webber, eds. The American Phytopathological Society, St. Paul, MN.

29. Molnar, A. C. 1965. Pathogenic fungi associated with a bark beetle on alpine fir. Can. J. Bot. 43:563-570.

30. Montgomery, D. C. 1991. Design and Analysis of Experiments. John Wiley \& Sons, New York.

31. Nevill, R. J., and Alexander, S. A. 1992. Pathogenicity of three fungal associates of Hylobius pales and Pissodes nemorensis (Coleoptera: Curculionidae) to eastern white pine. Can. J. For. Res. 22:1438-1440.

32. Owen, D. R., Lindahl, K. Q., Jr., Wood, D. L., and Parmeter, J. R., Jr. 1987. Pathogenicity of fungi isolated from Dendroctonus valens, D. brevicomis and $D$. ponderosae to ponderosa pine seedlings. Phytopathology 77:631-636.

33. Paine, T. D., Raffa, K. F., and Harrington, T. C. 1997. Interactions among scolytid bark beetles, their associated fungi, and live host conifers. Annu. Rev. Entomol. 42:179-206.

34. Parmeter, J. R., Jr., Slaughter, G. W., Chen, M.-M., Wood, D. L., and Stubbs, H. A. 1989. Single and mixed inoculations of ponderosa pine with fungal associates of Dendroctonus spp. Phytopathology 79:768-772.

35. Perry, T. J. 1991. A synopsis of the taxonomic revisions in the genus Ceratocystis including a review of bluestaining species associated with Dendroctonus bark beetles. U.S. Dep. Agric. For. Serv. Gen. Tech. Rep. $\mathrm{SO}: 86$.

36. Pfeffer, V. A., and Skuhravy, V. 1995. Der Buchdrucker (Ips typographus L.) (Col., Scolytidae) und seine Problematik in der Tschechischen Republik. Anz. Schädlingskd. Pflanzenschutz Umweltschutz 68:151-152.

37. Raffa, K. F. 1991. Induced defensive reactions in conifer-bark beetle systems. Pages 245-276 in: Phytochemical Induction by Herbivores. D. W. Tallamy and M. J. Raupp, eds. John Wiley \& Sons, New York.

38. Raffa, K. F., and Berryman, A. A. 1983. Physiological aspects of lodge- pole pine wound responses to a fungal symbiont of the mountain pine beetle, Dendroctonus ponderosae (Coleoptera: Scolytidae). Can. Entomol. 115:723-734.

39. Raffa, K. F., and Klepzig, K. D. 1992. Tree defense mechanisms against fungi associated with insects. Pages 354-389 in: Defense Mechanisms of Woody Plants Against Fungi. R. A. Blanchette and A. R. Biggs, eds. Springer-Verlag, Berlin.

40. Raffa, K. F., Phillips, T. W., and Salom, S. M. 1993. Strategies and mechanisms of host colonization by bark beetles. Pages 103-128 in: Beetle-Pathogen Interactions in Conifer Forests. T. D. Schowalter and G. M. Filip, eds. Academic Press, London.

41. Redfern, D. B., Stoakley, J. T., Steele, H., and Minter, D. W. 1987. Dieback and death of larch caused by Ceratocystis laricicola sp. nov. following attack by Ips cembrae. Plant Pathol. 36:467-480.

42. Safranyik, L., Shrimpton, D. M., and Whitney, H. S. 1983. The role of host-pest interaction in population dynamics of Dendroctonus rufipennis (Kirby) (Coleoptera: Scolytidae). Pages 197-212 in: The Role of InsectPlant Relationship in the Population Dynamics of Forest Pests. A. S. Isaev, ed. Proc. Int. Symp. Int. Union Forestry Res. Organ. (IUFRO)/UNESCO Program Man Biosphere (MAB). V. N. Sukacher Institute of Forst and Wood, Siberian Branch of the USSR Academy of Science, Krasnoyarsk.

43. Seifert, K. A. 1993. Sapstain of commercial lumber by species of Ophiostoma and Ceratocystis. Pages 141-151 in: Ceratocystis and Ophiostoma. Taxonomy, Ecology, and Pathogenicity. M. J. Wingfield, K. A. Seifert, and J. F. Webber, eds. The American Phytopathological Society, St. Paul, MN.

44. Solheim, H. 1986. Species of Ophiostomataceae isolated from Picea abies infested by the bark beetle Ips typographus. Nord. J. Bot. 6:199-207.

45. Solheim, H. 1988. Pathogenicity of some Ips typographus-associated blue-stain fungi to Norway spruce. Medd. Nor. Inst. Skogforsk. 40:1-11.

46. Solheim, H. 1992. Fungal succession in sapwood of Norway spruce infested by the bark beetle Ips typographus. Eur. J. For. Pathol. 22:136-148.

47. Solheim, H. 1993. Ecological aspects of fungi associated with the spruce bark beetle Ips typographus in Norway. Pages 235-242 in: Ceratocystis and Ophiostoma. Taxonomy, Ecology, and Pathogenicity. M. J. Wingfield, K. A. Seifert, and J. F. Webber, eds. The American Phytopathological Society, St. Paul, MN.

48. Solheim, H., and Safranyik, L. 1997. Pathogenicity of the spruce beetle associated blue-stain fungi, Ceratocystis rufipenni and Leptographium abietinum to Sitka spruce. Can. J. For. Res. 27:1336-1341.

49. Stephen, F. M., Berisford, C. W., Dahlsten, D. L., Fenn, P., and Moser, J. C. 1993. Invertebrate and microbial associates. Pages 129-153 in: BeetlePathogen Interactions in Conifer Forests. T. D. Schowalter and G. M. Filip, eds. Academic Press, London.

50. Visser, C., Wingfield, M. J., Wingfield, B. D., and Yamaoka, Y. 1995. Ophiostoma polonicum is a species of Ceratocystis sensu stricto. System. Appl. Microbiol. 18:403-409.

51. Weslien, J., Annila, E., Bakke, A., Bejer, B., Eidmann, H. H., Narvestad, K., Nikula, A., and Ravn, H. P. 1989. Estimating risks for spruce bark beetle (Ips typographus (L.)) damage using pheromone-baited traps and trees. Scand. J. For. Res. 4:87-98.

52. Whitney, H. S. 1982. Relationships between bark beetles and symbiotic organisms. Pages 183-211 in: Bark Beetles in North American Conifers. A System for the Study of Evolutionary Biology. J. B. Mitton and K. B. Sturgeon, eds. University of Texas Press, Austin.

53. Wood, S. L. 1982. The bark and ambrosia beetles of North and Central America (Coleoptera: Scolytidae), a taxonomic monograph. Great Basin Nat. Mem. 6:1-1359.

54. Wood, S. L., and Bright, D. E. 1992. A catalog of Scolytidae and Platypodidae (Coleoptera), part 2: Taxonomic index. Great Basin Nat. Mem. 13:1-1553. 